\title{
INFLUENCE OF DIFFERENT ADDITIVES ON THE MECHANICAL PERFORMANCE OF $\alpha$-HEMIHYDRATE GYPSUM FROM PHOSPHOGYPSUM
}

\author{
VPLIV RAZLIČNIH DODATKOV NA MEHANSKE LASTNOSTI \\ $\alpha$-HEMIHIDRATNEGA MAVCA SINTETIZIRANEGA IZ \\ FOSFATNEGA MAVCA
}

\author{
Hongbin Tan ${ }^{1,2 *}$, Aiguo Zheng ${ }^{3}$, Xiangmei Kang ${ }^{3}$, Ao Jiang ${ }^{3}$,Wanwei Fang ${ }^{4}$, \\ Yuchuan Liu' ${ }^{1}$, Jie Li ${ }^{1}$, Xiaochun He${ }^{1}$, Jinfeng Liu ${ }^{1}$ \\ ${ }^{1}$ State Key Laboratory of Environment-friendly Energy Materials, School of Materials Science and Engineering, Southwest University \\ of Science and Technology, Mianyang Sichuan 621010, China \\ ${ }^{2}$ Shaanxi Engineering Center of Metallurgical Sediment Resource, Shaanxi University of Technology, Hanzhong Shaanxi 723000, China \\ ${ }^{3}$ Deyang Rail Co., Ltd. of Chengdu Railway, Deyang Sichuan 618007, China \\ ${ }^{4}$ Xinjiang Changji Construction Group, Changji Xinjiang 831100, China
}

Prejem rokopisa - received: 2020-01-03; sprejem za objavo - accepted for publication: 2020-04-28

doi:10.17222/mit.2020.003

$\alpha$-hemihydrate gypsum is synthesized from phosphogypsum and the influence of a $\mathrm{CaO}$ treatment, the solution $\mathrm{pH}$ and a maleic acid addition on the microstructure have been systematically investigated. The influence of the resolvable phosphorous on the microstructure of hemihydrates gypsum can be reduced by $\mathrm{CaO}$ treatment. The mid-diameter of the columnar crystals decreases and the crystal surface becomes smooth with the solution $\mathrm{pH}$ decrease. Moreover, the addition of maleic acid changed the crystal growth direction and equiaxed $\alpha$-hemihydrates gypsum crystals were obtained in a $\mathrm{pH}=2$ solution. Furthermore, the effect of different additives, such as Portland cement and circulating fluidized bed slag, on the morphology and mechanical properties of hemihydrates gypsum was also studied. It was observed that the compressive strength decreased after the addition of Portland cement and circulating fluidized bed slag.

Keywords: phosphogypsum, $\alpha$-hemihydrates gypsum, crystal morphology, Portland cement, circulating fluidized bed slag,mechanical performance

Avtorji so sistematično raziskovali $\alpha$-hemihidratni mavec $\left(\mathrm{CaSO}_{4} \cdot 0,5 \mathrm{H}_{2} \mathrm{O}\right)$, ki so ga sintetizirali iz fosfatnega mavca. Analizirali so vpliv obdelave s $\mathrm{CaO}$, kislosti $(\mathrm{pH})$ raztopine in dodatka metanojske (mravljinčne) kisline na mikrostrukturo. Vpliv topnega fosforja na mikrostrukturo hemihidratnega mavca se lahko zmanjša s $\mathrm{CaO}$ obdelavo. Avtorji so ugotovili, da se povprečni premer stebričastih kristalov zmanjšuje in kristalna površina postaja bolj gladka z zmanševanjem $\mathrm{pH}$ raztopine. Nadalje ugotavljajo, da dodatek mravljinčne kisline spremeni smer rasti kristalov in pri pH raztopine je enako 2, nastajajo enakoosni kristali $\alpha$-hemihidratnega mavca. Študirali so tudi vpliv drugih dodatkov, kot je dodatek Portland cementa in žlindre iz vrtinčaste plasti, na morfologijo in mehanske lastnosti mavca. Ugotavljajo, da se tlačna trdnost mavca zmanjšuje z dodatkom Portland cementa in žlindre izdelane $\mathrm{v}$ vrtinčasti lebdeči plasti.

Ključne besede: fosfatni mavec, $\alpha$-hemihidratni mavec (gips), kristalna morfologija, Portland cement, žlindra iz vrtinčaste lebdeče plasti, mehanske lastnosti

\section{INTRODUCTION}

Phosphogypsum is a major solid waste, which is produced during phosphoric acid $\left(\mathrm{H}_{3} \mathrm{PO}_{4}\right)$ manufacturing by a wet acid process, and mainly consists of gypsum $\left(\mathrm{CaSO}_{4} \cdot 2 \mathrm{H}_{2} \mathrm{O}\right)$ and a minor amount of poorly crystalline $\mathrm{CaSO}_{4} \cdot 0.5 \mathrm{H}_{2} \mathrm{O}$, and crystalline $\mathrm{SiO}_{2} \cdot{ }^{1}$ In general, $4.5-5$ kilograms of phosphogypsum is generated for every kilogram of $\mathrm{P}_{2} \mathrm{O}_{5}$. Moreover, almost 55 million tons of phosphogypsum waste is generated annually in China and its annual output is estimated to be $\approx 280$ million tons worldwide. $^{2,3}$ Despite the fact that the phosphogypsum waste is utilized in numerous fields, such as soil stabilization amendments, agricultural fertilizers, cement retarder, building bricks/blocks and cementitious binder,

*Corresponding author's e-mail:

hb-t@163.com (Hogbin Tan) only a small fraction of phosphogypsum waste $(<10 w / \%)$ is reused and a large proportion is dumped in large stockpiles, which is exposed to the weathering process without any treatment. ${ }^{3,4}$ Phosphogypsum waste contains metals, organic substances and other potentially toxic elements, which raise potential environmental and health concerns. ${ }^{5}$ Therefore, recycling and the utilization of phosphogypsum waste cannot only save the natural gypsum but also protect the environment and human health. ${ }^{6}$ Moreover, it is of utmost importance to obtain value-added gypsum products by using phosphogypsum waste as a raw material. ${ }^{7}$

Even though six different gypsum phases are reported, only anhydrous gypsum $\left(\mathrm{CaSO}_{4}\right)$, hemihydrate gypsum $\left(\mathrm{CaSO}_{4} \cdot 0.5 \mathrm{H}_{2} \mathrm{O}\right)$ and dihydrate gypsum $\left(\mathrm{CaSO}_{4} \cdot 2 \mathrm{H}_{2} \mathrm{O}\right)$ are commonly found in the material universe. ${ }^{6}$ On the other hand, among gypsum-based prod- 
Table 1: Chemical composition of raw materials $(w / \%)$

\begin{tabular}{|l|c|c|c|c|c|c|c|c|c|c|c|c|c|}
\hline & $\mathrm{SO}_{3}$ & $\mathrm{CaO}$ & $\mathrm{SiO}_{2}$ & $\mathrm{Al}_{2} \mathrm{O}_{3}$ & $\mathrm{P}_{2} \mathrm{O}_{5}$ & $\mathrm{Fe}_{2} \mathrm{O}_{3}$ & $\mathrm{TiO}_{2}$ & $\mathrm{SrO}$ & $\mathrm{K}_{2} \mathrm{O}$ & $\mathrm{Na}_{2} \mathrm{O}$ & $\mathrm{MgO}$ & $\mathrm{F}$ & $\mathrm{O}$ thers \\
\hline Phosphogypsum & 50.75 & 37.88 & 7.2 & 1.54 & 0.88 & 0.77 & 0.24 & 0.22 & 0.2 & 0.08 & 0.06 & 0.1 & 0.24 \\
\hline Circulating fluidized bed slag & 23.74 & 27.01 & 26.26 & 12.5 & 0.89 & 3.11 & 0.78 & 0.45 & 0.84 & 1.42 & 2.69 & $/$ & 0.3 \\
\hline Portland cement & 3.95 & 59.61 & 23.01 & 4.66 & $/$ & 3.01 & $/$ & $/$ & $/$ & $/$ & 3.46 & $/$ & 2.3 \\
\hline
\end{tabular}

ucts, hemihydrates gypsum has the highest economic value.

Recently, much more attention is being paid to the morphological control of hemihydrate gypsum crystals, because the performance of hemihydrate gypsum in different applications is significantly influenced by the crystal morphology. ${ }^{8}$ For instance, acicular hemihydrate gypsum crystals (whiskers) are widely used as a reinforcement agent in different fields, such as rubbers, plastics, adhesives, friction materials, papermaking and environmental protection. ${ }^{9-11}$ Short-column hemihydrate gypsum crystals ( $\alpha$-hemihydrate gypsum) are being widely utilized in ceramics, molding, binders, industrial arts and architecture and construction industry. ${ }^{7}$ Furthermore, $\alpha$-hemihydrate gypsum powder, with a low aspect ratio, results in a paste with better injectability and mechanical properties. One should note that the setting behavior of $\alpha$-hemihydrate gypsum is closely related to the shape and size of the crystals. ${ }^{12}$ The morphology of hemihydrate gypsum crystals is influenced by organic additives and process parameters, such as the reaction time, reaction temperature and $\mathrm{pH}$ value. ${ }^{13-15} \mathrm{It}$ is worth mentioning that the organic additives are commonly utilized to control the morphology of hemihydrate gypsum crystals. For instance, F. Liu et al. ${ }^{12}$ have synthesized hemihydrate gypsum powder by a salt solution method and demonstrated that the morphology of hemihydrate gypsum crystals could be effectively modified by adding succinic acid. However, to obtain hemihydrate gypsum crystals with a uniform diameter and a smooth surface by using phosphogypsum waste, as a raw material, is a challenging task due to the presence of soluble phosphates. ${ }^{16}$

Moreover, gypsum products have a fatal weakness, i.e., poor water resistance. They can lose $75 \%$ of their strength after water absorption, and are prone to warpage. ${ }^{17}$ Therefore, their application is very limited, and the research on water-resistant gypsum has always been a subject of great importance. Portland cement and circulating fluidized bed slag can produce hydraulic cementitious materials, which would improve the $\alpha$-hemihydrates gypsum's water resistance. But the details are not clear.

Herein, the hydrothermal synthesis of $\alpha$-hemihydrate gypsum crystals has been carried out by using phosphogypsum waste as a raw material and the influence of calcium oxide $(\mathrm{CaO})$, solution $\mathrm{pH}$ and maleic acid addition on the morphology of $\alpha$-hemihydrate gypsum crystals has been systematically investigated. Moreover, the effect of different additives, including Portland cement and circulating fluidized bed slag, on $\alpha$-hemihydrates gypsum plaster properties has also been studied.

\section{EXPERIMENTAL PART}

Maleic acid, calcium oxide and sulphuric acid (Chengdu Kelong Chemical Reagent Co. Ltd., China), phosphogypsum waste (Lomon Co. Ltd., China). Polycarboxylic acid superplasticizer (Jiangyou Huafeng Building Materials Technology Co., Ltd, China). P. O 42.5R Portland cement (Beichuan Zhonglian Cement Co., Ltd, China). Circulating fluidized bed slag (Xinjiang Zhundong Shenhua Power Co., Ltd., China). The chemical composition of the as-received phosphogypsum, Portland cement and circulating fluidized bed slag is shown in Table 1.

The as-received phosphogypsum waste, water and $1.0 \mathrm{w} / \% \mathrm{CaO}$ were mixed by ball milling, and then, the mixture was dried at $40{ }^{\circ} \mathrm{C}$ for $24 \mathrm{~h}$ to obtain the calcified phosphogypsum, which possesses the $\mathrm{CaO}$ amount corresponding to the $\mathrm{P}$ content in phosphogypsum waste.

The gypsum and tap water were added, with a mass ratio of 1:5, in an autoclave. Then, sulphuric acid and/or maleic acid was added and the solution $\mathrm{pH}$ was changed during the addition of sulphuric acid. Then, the reaction system was stirred for $30 \mathrm{~min}$ by using an automatic mixer and then aged at $140{ }^{\circ} \mathrm{C}$ for $2 \mathrm{~h}$. Finally, the autoclave was naturally cooled to room temperature and the samples were filtered, dried at $105{ }^{\circ} \mathrm{C}$ for $24 \mathrm{~h}$ and milled to obtain $\alpha$-hemihydrates gypsum crystals powder.

The dry components ( $\alpha$-hemihydrates gypsum, with/without a $5 \mathrm{w} / \%$ circulating fluidized bed slag or/and a $5 w / \%$ Portland cement) were thoroughly handmixed. A $0.5 w / \%$ superplasticizer (when used) was dissolved in a measured amount of water. The dry mixture of $\alpha$-hemihydrates gypsum crystals was added in a certain amount of water and stirred with an automatic mixer. According to the normal consistency test, the water-to-gypsum ratio was fixed at 0.30 for samples with a superplasticizer. Finally, the homogeneous slurry was poured into a mold $(20 \times 20 \times 20) \mathrm{mm}^{3}$ and shaped through vibrations. After $24 \mathrm{~h}$ of hardening time, the molds were removed and then some of the samples were cured at a constant temperature of $25{ }^{\circ} \mathrm{C}$ and in relative humidity (RH) of $50 \%$ for $28 \mathrm{~d}$. Then, the samples were dried until a constant weight is obtained. And some of the samples were soaked in tap water for $24 \mathrm{~h}$ according to the Chinese standard (Gypsum blocks, JCT 698-2010), 
where the water surface was higher than the sample's top surface.

The water resistance of the samples is represented by a softening coefficient, which can be calculated by Equation $(1):{ }^{17}$

$$
k=f / f_{0}
$$

where $k$ refers to the softening coefficient, $f$ represents the strength of the soaked sample, $f_{0}$ corresponds to the strength of the dried sample with a constant weight.

The chemical composition of the raw materials was measured by a X-ray fluorescence spectrometer (AxiosPoly, PANalytical, Netherlands). The morphology was observed by scanning electron microscopy (TM-2000/ 4000, Hitachi, Japan). The phase analysis was carried out by using an X-ray powder diffractometer (Ultima IV, Rigaku, Japan), equipped with $\mathrm{Cu}-K_{\alpha}$ radiation $(\lambda=0.15406 \mathrm{~nm})$. The compressive strength was measured by using a microcomputer-controlled Electromechanical Universal Testing Machine (104C, Shenzhen Wance Testing Machine, China), under a loading rate of $0.02 \mathrm{kN} / \mathrm{s}$.

\section{RESULTS AND DISCUSSION}

\subsection{Effect of different factors on the gypsum crystalli- zation}

The scanning electron microscopy images of the sample, prepared from as-received phosphogypsum, are presented in Figure 1, which shows some columnar crystals (whiskers), with a high aspect ratio. The hemihydrates gypsum has been formed through a three-step dissolution-recrystallization process: the homogeneous nucleation of hemihydrates gypsum, self-assembly of hemihydrates gypsum aggregates and co-orientation along the c-axes, and the crystalline grain growth and whiskers formation. ${ }^{15}$ Hemihydrates gypsum normally crystallizes in the form of one-dimensional whiskers because the crystal lattice of the hemihydrates gypsum con-

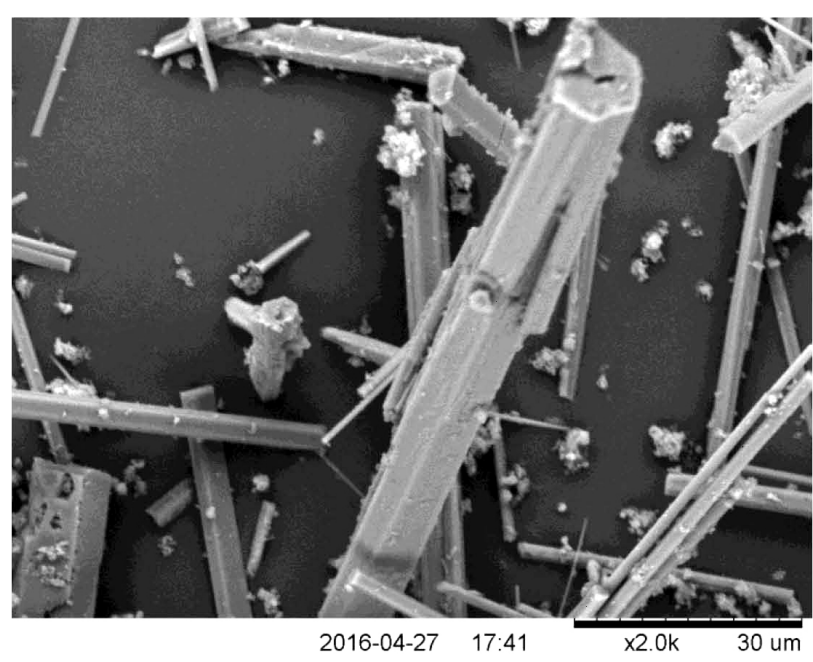

Figure 1: SEM of the sample prepared from received phosphogypsum sists of $-\mathrm{SO}_{4}-\mathrm{Ca}-\mathrm{SO}_{4}-\mathrm{Ca}-$ chains, where each $\mathrm{S}$ atom and four $\mathrm{O}$ atoms form a tetrahedron. These chains are hexagonally arranged and form a framework parallel to the $c$-axis, where one water molecule is attached to every two calcium sulfate molecules. ${ }^{18,19}$ However, the length and diameter of the hemihydrates gypsum crystals are not uniformly distributed and fascicular, short-columnar and gradual hemihydrates gypsum crystals have been observed. Moreover, some defects, i.e., holes, have also been observed on the surface of hemihydrates gypsum crystals due to the presence of resolvable phosphorus (e.g., free $\mathrm{H}_{3} \mathrm{PO}_{4}$ ) in as-received phosphogypsum. The influence of $\mathrm{PO}_{4}{ }^{3-}$ on the crystal morphology was mainly through the selective adsorption on specific crystal planes to alter the surface energy. During the hydrothermal process, the $\mathrm{PO}_{4}{ }^{3-}$ molecules tend to absorb on the polar crystal faces rather than the prismatic faces, which would inhibit the crystal growth along the polar planes. ${ }^{15}$ On the other hand, some crystals with defects have been observed due to the adsorption of excessive amount of $\mathrm{PO}_{4}{ }^{3-}$ ions on prismatic faces.

Free $\mathrm{H}_{3} \mathrm{PO}_{4}$ in phosphogypsum can easily react with $\mathrm{CaO}$ to obtain $\mathrm{Ca}_{3}\left(\mathrm{PO}_{4}\right)$. Additionally, $\mathrm{CaHPO}_{4}$ in phosphogypsum can also react with $\mathrm{CaO}$ to obtain $\mathrm{Ca}_{3}\left(\mathrm{PO}_{4}\right)$, accounting for the different $\mathrm{K}_{\mathrm{sp}}$ at $25{ }^{\circ} \mathrm{C}$ $\left(1.0 \times 10^{-7}\right.$ for $\mathrm{CaHPO}_{4}$ and $2.0 \times 10^{-29}$ for $\left.\mathrm{Ca}_{3}\left(\mathrm{PO}_{4}\right)_{2}\right)$. Compared with $\mathrm{CaSO}_{4} \cdot 2 \mathrm{H}_{2} \mathrm{O}$ and $\mathrm{CaSO}_{4} \cdot 0.5 \mathrm{H}_{2} \mathrm{O}$, $\mathrm{Ca}_{3}\left(\mathrm{PO}_{4}\right)_{2}$ were more stable under the experimental conditions owing to the different $\mathrm{K}_{\mathrm{sp}}$ at $135^{\circ} \mathrm{C}\left(5.16 \times 10^{-6}\right.$ for $\mathrm{CaSO}_{4} \cdot 2 \mathrm{H}_{2} \mathrm{O}, 4.53 \times 10^{-6}$ for $\mathrm{CaSO}_{4} \cdot 0.5 \mathrm{H}_{2} \mathrm{O}$, and $9.41 \times 10^{-40}$ for $\left.\mathrm{Ca}_{3}\left(\mathrm{PO}_{4}\right)_{2}\right) \cdot{ }^{16,18}$ As a result, the effect of phosphorus on the hemihydrates gypsum growth can be decreased by adding calcium oxide in phosphogypsum. ${ }^{18}$

The scanning electron microscopy micrographs of the samples prepared from calcified phosphogypsum in different $\mathrm{pH}$ solution are shown in Figure 2. The average diameter of the columnar crystals decreased and the crystal surface became smooth, while the solution $\mathrm{pH}$ decreased. Some particles on the crystal surface were observed, because the calcium sulphate has a low dissolution rate in a high $\mathrm{pH}$ solution $(\mathrm{pH}=6)$ and some $\mathrm{CaSO}_{4} \cdot 2 \mathrm{H}_{2} \mathrm{O}$ did not take part in the reaction (Figure 2a). Some columnar crystals with a smooth surface, an aspect ratio of 2-10 and an average diameter of 0.5-4 $\mu \mathrm{m}$ have also been observed in a $\mathrm{pH}=5$ solution (Figure 2 b). Columnar crystals, with smooth surface and a $2-10$ in aspect ratio, were obtained, and the $\mathrm{pH}$ of the solution was 2 (Figure 2c). The crystals' distributions in terms of the length and diameter are also not uniform, but fascicular and gradual products were not observed. The uniform whiskers were observed in the sample $(\mathrm{pH}=0.5$ in solution), with a $20-50$ in aspect ratio, $0.5-2 \mu \mathrm{m}$ in diameter and a smooth surface (Figure 6c). The low $\mathrm{pH}$ value of the solution can promote the $\mathrm{CaSO}_{4} \cdot 2 \mathrm{H}_{2} \mathrm{O}$ dissolution, which is favorable to crystal growth. 

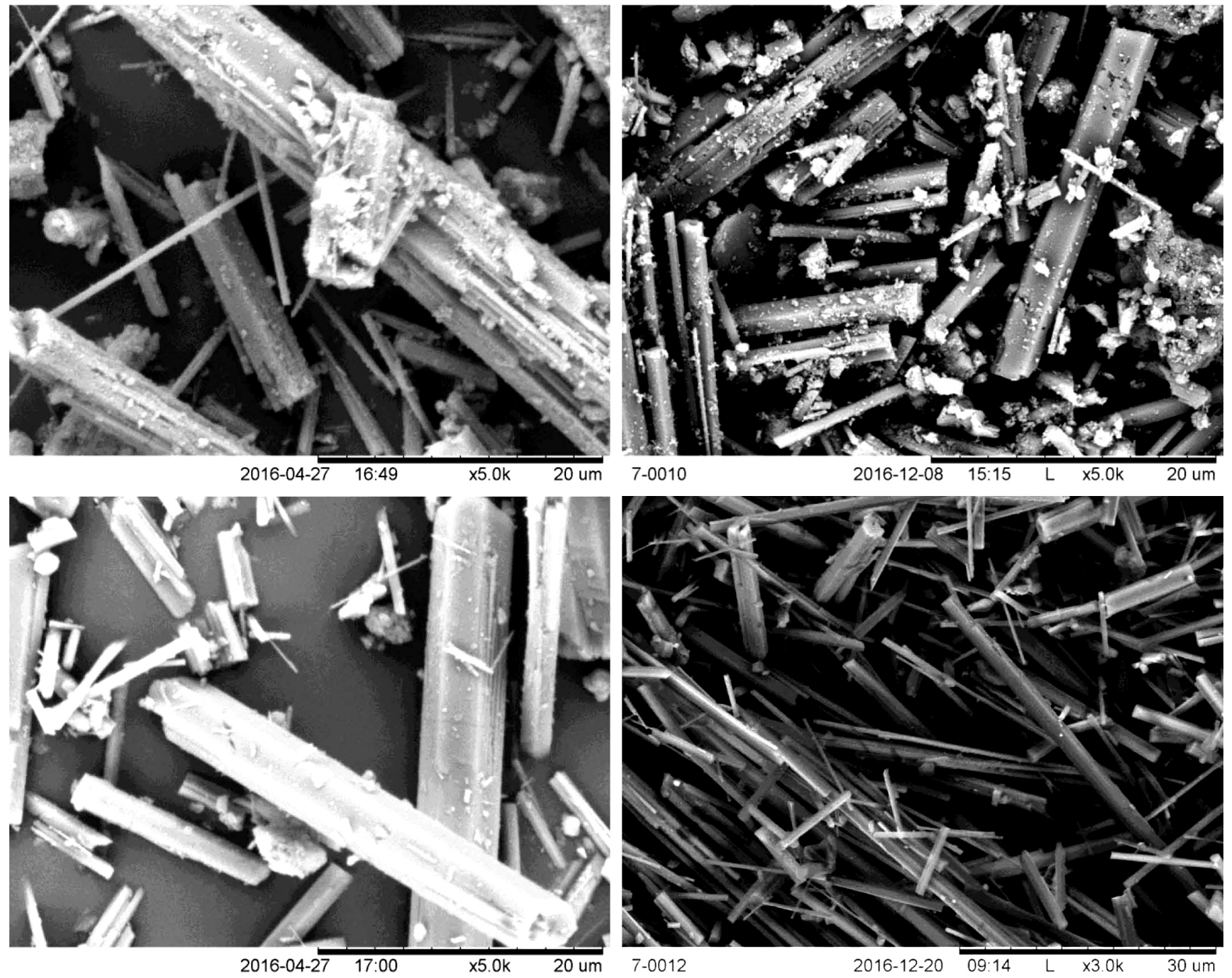

Figure 2: SEM of the samples prepared from calcified phosphogypsum in different $\mathrm{pH}$ solutions a) $\mathrm{pH}=6, \mathrm{~b}) \mathrm{pH}=5$, c) $\mathrm{pH}=2$, d) $\mathrm{pH}=0.5$

The X-ray powder diffractometer patterns of the samples prepared from calcified phosphogypsum in different $\mathrm{pH}$ solution are shown in Figure 3. The peaks are similar for the sample prepared in the $\mathrm{pH}=6$ and 2 solutions, indicating that the phases of the samples were calcium sul-

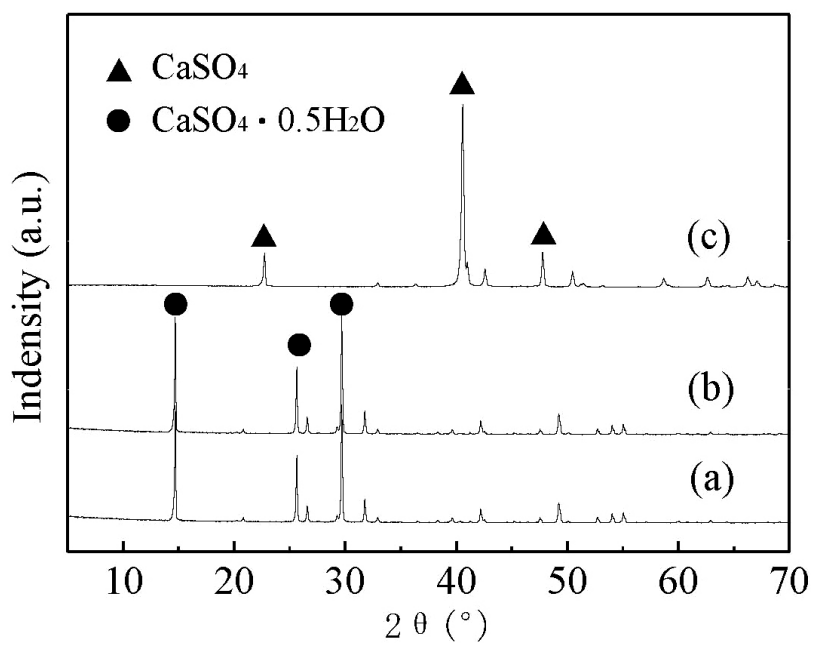

Figure 3: XRD patterns of the samples prepared from calcified phosphogypsum in different $\mathrm{pH}$ solutions $\mathrm{pH}=\mathrm{a}) 6$, b) 2 and c) 0.5 fate hemihydrate $\left(\mathrm{CaSO}_{4} \cdot 0.5 \mathrm{H}_{2} \mathrm{O}\right)$ (Figure 3a and 3b). But the phase of the sample prepared in the $\mathrm{pH}=0.5$ solution was anhydrous calcium sulfate, because the structure easily forms at high hydrothermal temperature in a low $\mathrm{pH}$ solution (Figure 3c).

The scanning electron microscopy images of the sample, prepared from calcified phosphogypsum with maleic acid in $\mathrm{pH}=5$ solution, are shown in Figure 4. Some equiaxed crystals ( $\alpha$-hemihydrates gypsum), with a diameter of 1-5 $\mu \mathrm{m}$ and a smooth surface, have also been observed due to the addition of maleic acid. It is worth mentioning that the organic acid can be selectively adsorbed on different crystal faces and alters their surface energy. Hence, the growth rate along the different crystal axes is influenced by the presence of maleic acid, which leads to the formation of different morphologies and renders different crystallite sizes. ${ }^{8}$ First, the maleic acid absorbed on the polar crystal faces due to their high binding energy, which resulted in the formation of equiaxed crystals. One should note that the low $\mathrm{pH}$ solution can promote the $\mathrm{CaSO}_{4} \cdot 2 \mathrm{H}_{2} \mathrm{O}$ dissolution, which favors the crystal growth. Therefore, the smooth-surface crystals were obtained due to the addition of maleic acid, which reduced the $\mathrm{pH}$ value of that solution. 


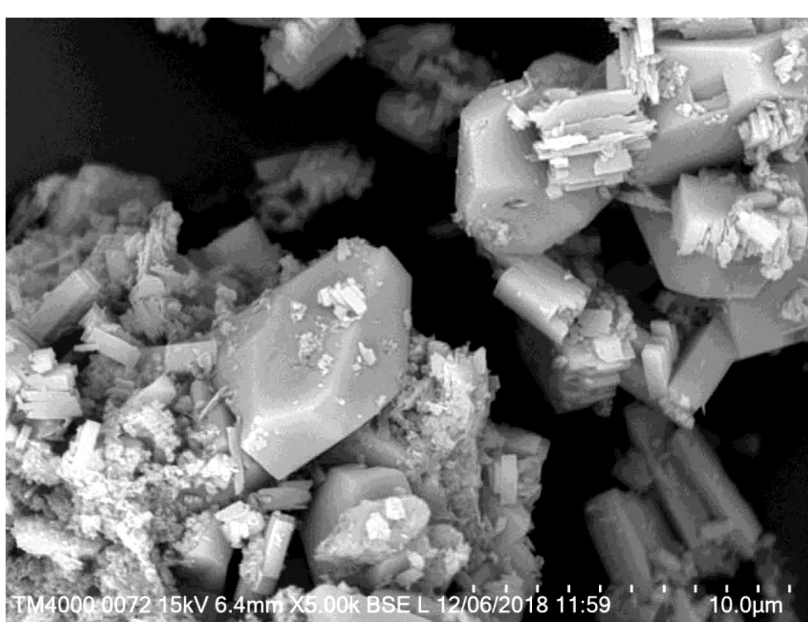

Figure 4: SEM of the samples prepared from calcified phosphogypsum with maleic acid in $\mathrm{pH}=5$ solution

Furthermore, X-ray powder diffractometer patterns of the samples from calcified phosphogypsum in $\mathrm{pH}=5$ solution, with and without the addition of $0.05 \mathrm{w} / \%$ maleic acid, are presented in Figure 5. The diffraction peaks from the different samples coincide with each other, indicating that different samples contain the same hemihydrates gypsum $\left(\mathrm{CaSO}_{4} \cdot 0.5 \mathrm{H}_{2} \mathrm{O}\right)$ phase. The crystal structure of the gypsum is mainly influenced by the temperature and hemihydrates gypsum crystals have been obtained at the hydrothermal temperature of $110{ }^{\circ} \mathrm{C}$.

\subsection{Effect of additives on $\alpha$-hemihydrates gypsum me- chanical properties}

The compressive strength of the samples, with different additives, is presented in Figure 6. It can be readily observed that the compressive strength decreased, and the softening coefficient increased due to the addition of different additives. The dried and soaked average strengths of $\alpha$-hemihydrates gypsum were found to be 25.1 $\mathrm{MPa}$ and 8.2 $\mathrm{MPa}$, respectively. Moreover, the dried

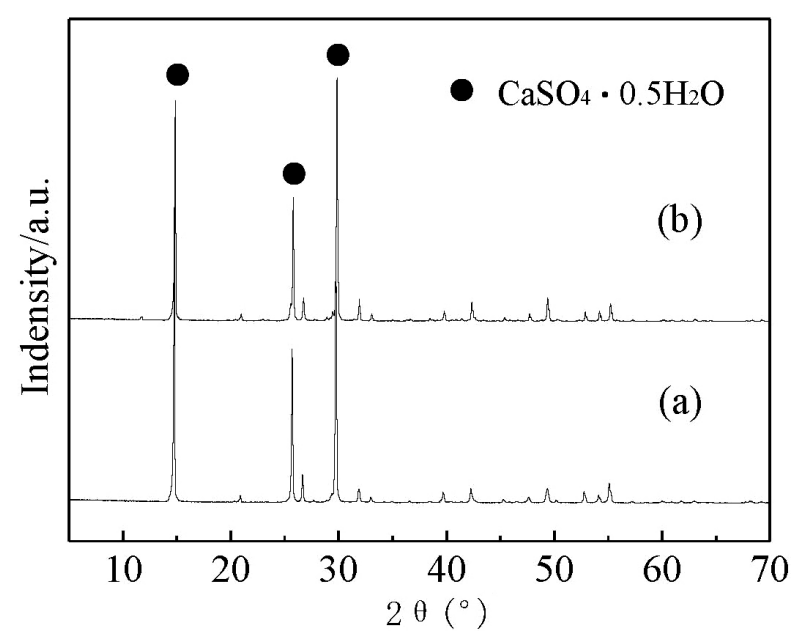

Figure 5: XRD of the sample a) with and b) without maleic acid from calcified phosphogypsum in $\mathrm{pH}=5$ solution

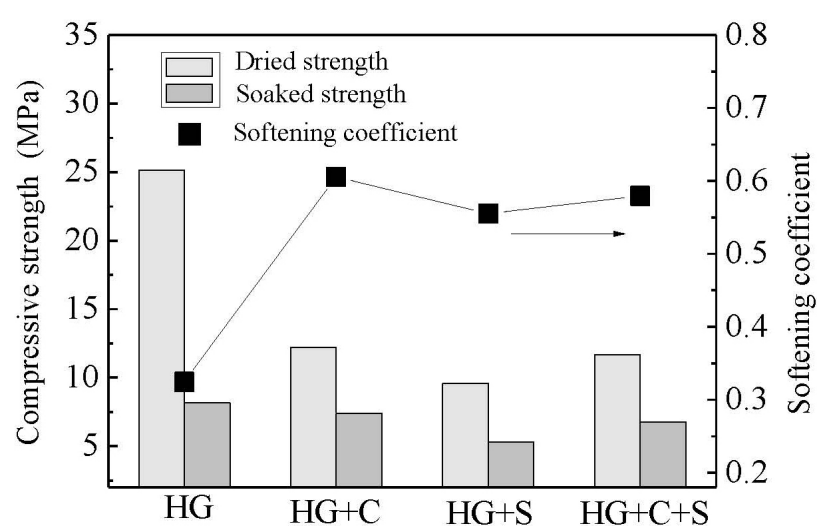

Figure 6: Compressive strength of the samples with different additives. HG: a-hemihydrate gypsum, C: Portland cement, S: circulating fluidized bed slag

average strength of (12.2, 9.6 and 11.7) $\mathrm{MPa}$ has been obtained after the addition of Portland cement, circulating fluidized bed slag and cement/circulating fluidized bed slag mixture into a-hemihydrates gypsum crystals. The softening coefficient increased with the addition of cement and circulating fluidized bed slag due to the generation of hydraulic cementitious materials.

The scanning electron microscopy images of the samples, with different additives, are shown in Figure 7. The plate-like and needle-like gypsum crystals, with a large length-to-radius ratio, have been observed and a dense microstructure has been formed due to the interlocking of these plate-like and needle-like crystals (Figure 7a). It can be clearly observed that the microstructure of gypsum has been significantly altered due to the presence of different additives. The addition of Portland cement slightly changed the appearance of the gypsum crystals, which exhibited larger and irregular crystals and a loose microstructure (Figure 7b). Interestingly, a large number of small particles, adsorbed on the surface of large crystals, exhibited a negligible amount of interlocking, which led to the formation of the loose microstructure. Furthermore, the gypsum crystal appearance has also been slightly changed due to the addition of circulating fluidized bed slag and the irregular and prismatic crystals have exhibited a loose microstructure (Figure 7c). The globular particles from the circulating fluidized bed slag rendered a rough surface and exhibited a little hydration reaction in the gypsum system. In the case of the hemihydrates gypsum + Portland cement + circulating fluidized bed slag sample, a similar microstructure has been observed (Figure 7d).

Moreover, these scanning electron microscopy observations are consistent with the measured mechanical strength of the different samples. One should note that the mechanical strength has a direct relationship with the degree of interlocking. Therefore, the formation of a loose microstructure due to the addition of Portland cement and circulating fluidized bed slag resulted in a reduced mechanical strength. 

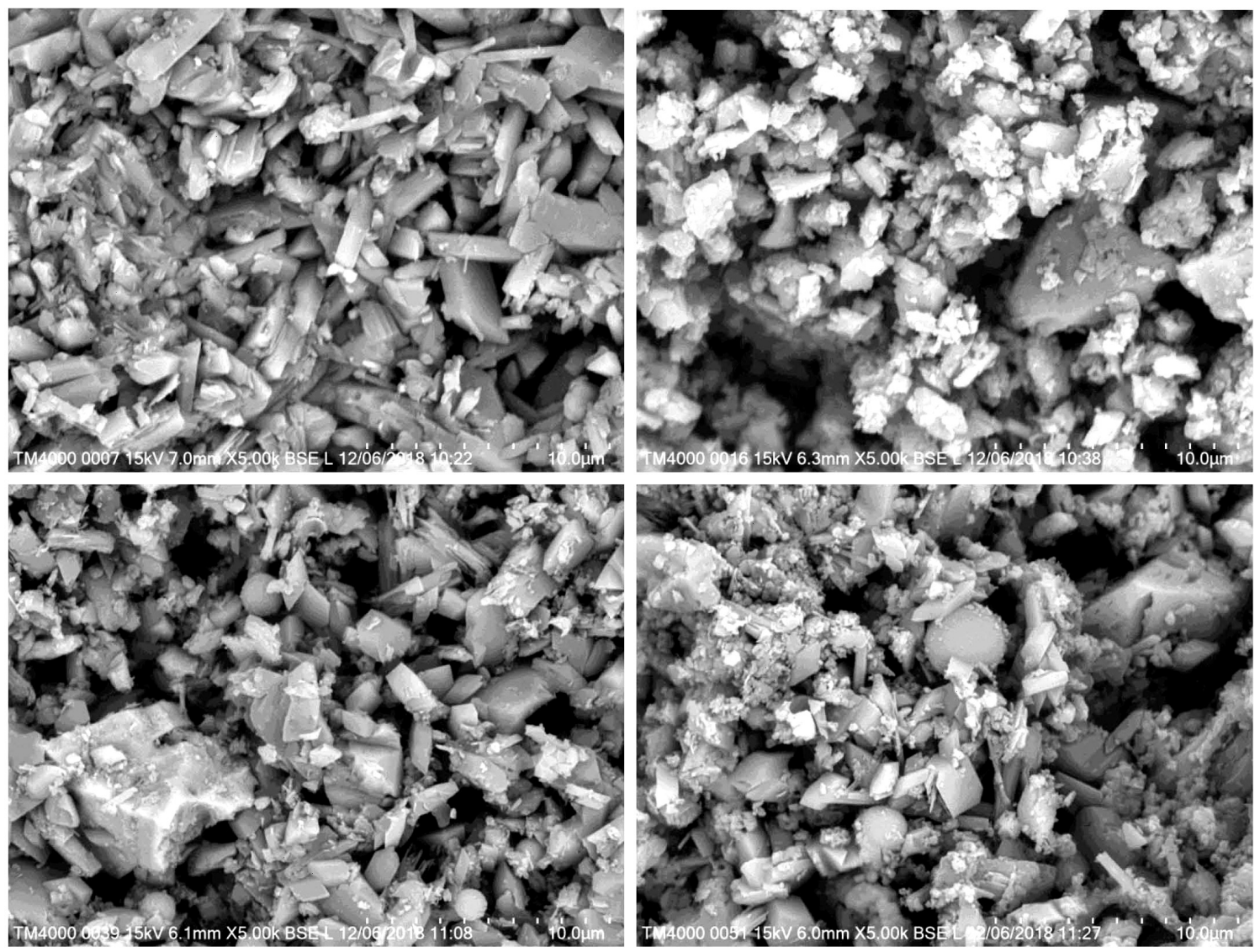

Figure 7: SEM of the samples with different additives: a) $\mathrm{HG}$, b) $\mathrm{HG}+\mathrm{C}$, c) $\mathrm{HG}+\mathrm{S}, \mathrm{d}) \mathrm{HG}+\mathrm{C}+\mathrm{S}$ HG: a-hemihydrate gypsum, C: Portland cement, S: circulating fluidized bed slag

Furthermore, the phases of the Portland cement and the circulating fluidized bed slag contain calcium minerals. When they react with water, the minerals hydrate and $\mathrm{Ca}(\mathrm{OH})$ can be released. As a result, the $\mathrm{pH}$ value of slurry can change during the gypsum hydration. The dissolution rate and the amount of dissolved $\alpha$-hemihydrates gypsum particles are remarkably influenced by the $\mathrm{pH}$ value of the solution, which further affects the length-to-radius ratio of the gypsum crystals. Therefore, the influence of the $\mathrm{pH}$ value on the hydration process alters the microstructure and dictates the mechanical strength. ${ }^{20}$

\section{CONCLUSIONS}

The resolvable phosphorus from the as-received phosphogypsum remarkably influenced the microstructure of the hemihydrates gypsum. However, the influence of phosphorous can be reduced by a $\mathrm{CaO}$ treatment. The solution $\mathrm{pH}$ can influence the crystal structure and morphology. Moreover, maleic acid has exhibited surface adsorption on the selective crystal faces and altered the growth direction of hemihydrates gypsum grains, which resulted in the formation of equiaxed $\alpha$-hemihydrates gypsum crystals. Furthermore, the addition of Portland cement and circulating fluidized bed slag significantly altered the mechanical properties and microstructure of the as-synthesized $\alpha$-hemihydrate gypsum. For instance, the compressive strength of $\alpha$-hemihydrate gypsum decreased from 25.1 MPa to (12.2, 9.6 and 11.7) MPa after the addition of Portland cement, circulating fluidized bed slag and cement/circulating fluidized bed slag mixture, respectively.

\section{Acknowledgements}

This work was supported by the Research Fund of the Sichuan Science and Technology Program of China (19ZDYF2817, 2018RZ0040, 20ZDYF1154) and Natural Science Foundation of Southwest University of Science and Technology (19zx7130, 18zx7101).

\section{REFERENCES}

${ }^{1}$ O. Hentati, N. Abrantes, A. L. Caetano, S. Bouguerra, F. Gonçalves, J. Rombke, R. Pereira, Phosphogypsum as a soil fertilizer: Ecotoxicity of amended soil and elutriates to bacteria, invertebrates, algae and plants, Journal of Hazardous Materials, 294 (2015), 80-89, doi:10.1016/j.jhazmat.2015.03.034

${ }^{2}$ M. Contreras, R. Pérez-López, M. J. Gázquez, V. Morales-Florez, A. Santos, L. Esquivias, J. P. Bolivar, Fractionation and fluxes of metals and radionuclides during the recycling process of phosphogypsum wastes applied to mineral $\mathrm{CO}_{2}$ sequestration, Waste Management, 45 (2015), 412-419, doi:10.1016/j.wasman.2015.06.046 
${ }^{3}$ Y. Shen, J. Qian, J. Chai, Y. Fan, Calcium sulphoaluminate cements made with phosphogypsum: Production issues and material properties, Cement \& Concrete Composites, 48 (2014), 67-74, doi:10.1016/j.cemconcomp.2014.01.009

${ }^{4} \mathrm{M}$. Zielinski, Influence of constant magnetic field on the properties of waste phosphogypsum and fly ash composites, Construction and Building Materials, 89 (2015), 13-24, doi:10.1016/j.conbuildmat. 2015.04.029

${ }^{5}$ A. A. Cuadria, F. J. Navarroa, M. García-Moralesa, J. P. Bolívar, Valorization of phosphogypsum waste as asphaltic bitumen modifier, Journal of Hazardous Materials, 279 (2014), 11-16, doi:10.1016/ j.jhazmat.2014.06.058

${ }^{6}$ H. He, F. Dong, P. He, L. Xu, Effect of glycerol on the preparation of phosphogypsum-based $\mathrm{CaSO}_{4} \cdot 0.5 \mathrm{H}_{2} \mathrm{O}$ whiskers, Journal of Materials Science, 49 (2014), 1957-1963, doi.10.1007/s10853-013-7825-4

${ }^{7}$ B. Guan, L. Yang, H. Fu, B. Kong, T. Li, L. Yang, $\alpha$-calcium sulfate hemihydrate preparation from FGD gypsum in recycling mixed salt solutions, Chemical Engineering Journal, 174 (2011) 1, 296- 303, doi:10.1016/j.cej.2011.09.033

${ }^{8}$ X. Mao, X. Song, G. Lu, Y. Xu, Y. Sun, J. Yu, Effect of additives on the morphology of calcium sulfate hemihydrate: Experimental and molecular dynamics simulation studies, Chemical Engineering Journal, 278 (2015), 320-327, doi:10.1016/j.cej.2014.10.006

${ }^{9}$ X. Feng, Y. Zhang, G. Wang, M. Miao, L. Shi, Dual-surface modification of calcium sulfate whisker with sodium hexametaphosphate/silica and use as new water-resistant reinforcing fillers in papermaking, Powder Technology, 271 (2015), 1-6, doi:10.1016/j.powtec.2014.11.015

${ }^{10}$ Z. Zhu, L. Xu, G. Chen, Effect of different whiskers on the physical and tribological properties of non-metallic friction materials, Materials and Design, 32 (2011) 1, 54-61, doi:10.1016/j.matdes. 2010.06.037

${ }^{11}$ X. Chen, L. Yang, J. Zhang, Y. Huang, Exploration of As(III)/As(V) Uptake from Aqueous Solution by Synthesized Calcium Sulfate Whisker, Chinese Journal of Chemical Engineering, 22 (2014) 11-12, 1340-1346, doi:10.1016/j.cjche.2014.09.018

${ }^{12}$ F. Li, J. Liu, G. Yang, Z. Pan, X.Ni, H. Xu, Q. Huang, Effect of pH and succinic acid on the morphology of $\alpha$-calcium sulfate Hemihydrate synthesized by a salt solution method, Journal of Crystal Growth, 374 (2013), 31-36, doi:10.1016/j.jcrysgro.2013.03.042
${ }^{13}$ C. Hazra, S. Bari, D. Kundu, A. Chaudhari, S. Mishra, A. Chatterjee, Ultrasound-assisted /biosurfactant-templated size-tunable synthesis of nano-calcium sulfate with controllable crystal morphology, Ultrasonics Sonochemistry, 21 (2014) 3, 1117-1131, doi:10.1016/j.ultsonch.2013.12.020

${ }^{14}$ J. Mao, G. Jiang, Q. Chen, B. Guan, Influences of citric acid on the metastability of \#-calcium sulfatehemihydrate in $\mathrm{CaCl} 2$ solution, Colloids and Surfaces A: Physicochemical and Engineering Aspects, 443 (2014), 265- 271, doi:10.1016/j.colsurfa.2013.11.023

${ }^{15}$ B. Kong, J. Yu, K. Savino, Y. Zhu, B. Guan, Synthesis of $\alpha$-calcium sulfate hemihydrate submicron-rods in water/n-hexanol/CTAB reverse microemulsion, Colloids and Surfaces A: Physicochemical and Engineering Aspects, 409 (2012), 88-93, doi:10.1016/j.colsurfa. 2012.05.041

${ }^{16}$ F. Dong, Z. Huang, H. Tan, C. Wu, P. He, Effect of additives on calcium sulfate hemihydrate whiskers morphology from calcium sulphate dehydrate and phosphogypsum, Materials and Manufacturing Processes, 31 (2016), 2037-2043, doi:10.1080/10426914.2016. 1176184

${ }^{17}$ Q. Wu, H. Ma, Q. Chen, B. Gu, S. Li, H. Zhu, Effect of silane modified styrene-acrylic emulsion on the water-proof properties of flue gas desulfurization gypsum, Construction and Building Materials, 197 (2019), 506-512, doi:10.1016/j.conbuildmat.2018.11.185

${ }^{18}$ X. Wang, L. Yang, X. Zhu, J. Yang, Preparation of calcium sulfate whiskers from FGD gypsum via hydrothermal crystallization in the $\mathrm{H}_{2} \mathrm{SO}_{4}-\mathrm{NaCl}-\mathrm{H}_{2} \mathrm{O}$ system, Particuology, 17 (2014), 42-48, doi:10.1016/j.partic.2013.12.001

${ }^{19}$ Q. Han, K. Luo, H. Li, L. Xiang, Influence of disodium hydrogen phosphate dodecahydrate on hydrothermal formation of hemihydrate calcium sulfate whiskers, Particuology, 17 (2014), 131-135, doi:10.1016/j.partic.2013.10.002

${ }^{20}$ X. Chen, J. Gao, C. Liu, Y. Zhao, Effect of neutralization on the setting and hardening characters of hemihydrate phosphogypsum plaster, Construction and Building Materials, 190 (2018), 53-64, doi:10.1016/j.conbuildmat.2018.09.095 